\title{
Review
}

\section{Review of Absorption Oil Content in Water Injection}

Aditya Nugraha Ernawan, Alfi Fachrizal, Angga Wijaya, Bima Syahreza, Muhammad Ridwan

Alkhandi, Mayang Firdaus, Mulyono Dyatmahendri, Rizka Ananda, Wily Rustam*, Muhammad Khoirul Afdhol and TomiErfando

\author{
Department of Petroleum Engineering, Universitas Islam Riau, Jalan Kaharuddin Nasution No. 113, \\ Pekanbaru 28284, Indonesia; adityane@student.uir.ac.id (A.N.E.); alfifachrizal@student.uir.ac.id (A.F.); \\ angga18wijaya@student.uir.ac.id (A.W.); bima.syahreza0205@student.uir.ac.id (B.S.); afdhol@eng.uir.ac.id \\ (M.K.A.); mridwanalkhandi@student.uir.ac.id (M.R.A.); mayangfirdaus@student.uir.ac.id (M.F.); \\ mulyono@student.uir.ac.id (M.); rizkaananda13@student.uir.ac.id (R.A.); tomierfando@eng.uir.ac.id (T.E.); \\ wilyrustam@student.uir.ac.id (W.R.) \\ * Correspondence: wilyrustam@student.uir.ac.id
}

\begin{abstract}
Implementation of waterflood is with injected pressured water to reservoir to escalation oil production. Produced water is the dominated result from oil and gas mechanism in this world meanwhile $65 \%$ of water is injected back to the well for pressure maintenance, $30 \%$ for discharge aquifier condition and surface. For shaly sand, produced water usually bring coarse and suspended sand to the surface. Therefore, this sand level is needed to declining to avoid plugging in injection well until certain economic condition.
\end{abstract}

Keywords: absorption; oil content; water injection; treatment

\section{Introduction}

Produced water is the biggest further product from oil production with oil-water ratio in global is $4: 1$ [1][2][3]. The production of water from a well will increase and be the main flowing in the production process. Therefore, it needs a strategy to determine the water must be removed to the high seas, desert area as evaporation pond, injected back to the formation for maintaining pressure, EOR, and others [4][5][6]. This water contains an organic and inorganic compound depending on geography position, hydrocarbon properties, formation layer, and reservoir microorganism composition [7][8][9]. Before doing the process, it is important to do the purification process or cleaning the water from impurities including oil that still exist in the water [10][11]. At this time, it has been so many oilfields that using water as injected water to sweep oil or the term is a waterflood [12][13]. However, the treatment is needed for injected water to increase water quality and reduced solid suspension in the water so that the plug is not happening while injection [14][15]. The main water source for waterflood method is produced water to reduce the possibility of the heap, bacteria growth, and swelling caused by compatibility with air formation [6] [14-17]. Water spill oily in the large amount will affect to the environment pollution and society life [18-20]. Some methods have been used to remove oil in water emulsion including absorption, filtration, osmosis reverse, biology process, air flotation, membrane bioreactor, chemical coagulation, electrocoagulation, and electroporation [21]. Other than that, there is a centrifuge test, hydro cyclone, membrane, and corrosion inhibitor to reduce the oil content in the water [22].

\section{Methods}

\section{Absorption}

There are a lot of conventional methods like flocculation, coagulation, absorption, membrane technique, and others. The absorption method shows high efficiency because of the simple process, friendly environment, low cost, and easy recovery absorption [21] [23-26]. 


\section{Gas Flotation}

The gas flotation method is the particle cleaning method that settles in the fluid using gas and brings it to the surface. Then, the last configuration is the injection air bubble with a diameter of less than $100 \mu \mathrm{m}$ into the flotation tank through a needle valve or nozzle. Four types of polymer have been used with weight molecule variation and density. A heavy polymer is hydra cool 882 and 864 while a light polymer is a hydra cool 852 and 1142 . This material has been saved in $5^{\circ} \mathrm{C}$ for one week. Aluminum sulfate has been used to test the coagulation from the sample [28]. Gas flotation method may develop, one of it is with adding coal as oil-absorbent media in the water [29][6][30][4]. With this addition, there are three main processes will happen. First, the diffusion process in the oil molecule to a substrate continues with the capillary force existence so that the oil is removed and absorb to the coal [30]. The tested parameter is coal type, absorb time and coal size. It will happen 3 phenomena in this experiment process, there are diffusion, capillary action, and $\mathrm{pH}$ impact to the concentration that absorbed. Polyethyleneimine efficiency as a flocculant in removing oil in the production water. Compare with Removal efficiency high molecule and Polyethyleneimine low molecule. The high SDBS concentration, the high removal efficiency Polyethyleneimine. In DAF system, Polyethyleneimine high molecule shows a better result than a low molecule and the high removal efficiency starts from 100 ppm SDBS [31].

\section{Cyclones Separation}

EOR injection with polymer will difficult to process than waterflood. When quality water of waterflood increases, it needs 6 hours so that the polymer flood needs 12 hours. Therefore, it needs new technology to increment the water quality of the polymer flood. Double Cone Air Sparged Hydro Cyclone (DcASH) method is the answer for it [32][33].

\section{Membrane}

Membrane technology has been the main component in schematic water reclamation because it provides high-quality water [34-35]. Other than that, this technique has a low cost to get the produce waste thing. Microfiltration (MF) is only able to remove ingredients that suspended, generally the size approximately $0.05 \mu \mathrm{m}$ [30]. Therefore, MF only denies the material. Ultrafiltration (UF) can remove keloid and macromolecule solution, generally able to deny the material where size is 0.005 $0.5 \mu \mathrm{m}$ and particle Nano Filtration (NF) $0.0007-0.005 \mu \mathrm{m}$. Meanwhile, Reverse Osmosis (RO) is able to filtrate almost the high contaminant than a water molecule. Membrane usually forms from woven fibre, ceramics, polymer or metal material [16][38]. Ultrafiltration (UF) is one of the methods more effective to process wastewater than traditional removal method because of the high removal oil efficiency, no chemical addition, low-cost energy, and small room [32]. UF membrane method is eminent because membrane cleaning method to oil is reduced from 4.6 days to 2 days with the increasing oil concentration from $95 \mathrm{ppm}$ to $187 \mathrm{ppm}$. With this result, operation cost with water targeted produced $25000 \mathrm{BPD}$ with $<2 \mathrm{mg} / \mathrm{L}$ oil estimated $9.7 \mathrm{sen} / \mathrm{bbl}$ and water recovery also exceed $98 \%$.

There are so many methods have been used in water treatment or oil absorption i.e. synthetic polymer is used with hydrophobic absorption characteristic and oleophilic. For example, polyurethane, Polypropylene, polyethene dan butyl. However, the weakness of synthetic polymer is a slow decomposition and this material tend to foul with blocking the pore surface. The second, the material has been used has low absorption, for example, corn stalk, bagasse pith, nonwoven wool, and cotton fibres. The third, inorganic sorbents are the most used ingredient, for example, vermiculite, exfoliated, graphite, sepiolite, zeolites, and CNTs [39].

Membrane filtration is useful in oil removal process [40][41]. Polymer membrane is sensitive to polar solvent and dechlorination, and high oil fraction. Ceramic membrane especially zirconia membrane shows a better removal result like high flux. For oil content from permeate has been analyzed using spectrometry UV [42] and COD value is determined on the conventional oxidation process. Using double functional membrane that covered by PDA/PEPA/SH at the same time can remove oil from water and absorb mercury ion in the water through affinity interaction in reverse 
and more efficient. The double functional membrane can remove oil/water mixing and absorb pollution solvent in reversible. Other than that, it can use in a few times and maintain removal efficiency and high absorption whereas this will decrease wastewater process cost and have a big potential in an industry. It has been indicated that the membrane still has strong absorption capacity and high removal efficiency after five times are used [43].

\section{Woven Fibre Membrane}

Woven fibre membrane (WFMF) is a woven based on polyester sourced locally and provides by Gelvenor Consolidated Fabrics (PTY) Ltd. in Durban, South Africa. Membrane pore size is unknown. Therefore, it determined using exception method modification (MSE). The test is doing with WFMF placed on filtrate paper. The turbidity is compared with individual filter paper and deionization water to check the denied percentage. The size of WFMF pore membrane is concluded same with filtrate paper with the same denied capacity [44].

\section{Ceramic Membrane}

The raw material is used to prepare ceramic membrane is Red Clay (RC) Maroco from Safi and Phosphate is extracted from Youssoufia (Maroco). The main chemical material percentage to make $\mathrm{RC}$ is $\mathrm{SiO} 2(52,79 \mathrm{wt} \%), \mathrm{Al} 2 \mathrm{O} 3(17,44 \mathrm{wt} \%), \mathrm{Fe} 2 \mathrm{O} 3(5,08 \mathrm{wt} \%)$. Almost of the Phosphate is rich with P2O5 (19,94 wt\%) dan $\mathrm{CaO}(39,34 \mathrm{wt} \%)$. It also contains $\mathrm{SiO} 2(9,26 \mathrm{wt} \%)$ dan low amount of $\mathrm{Al} 2 \mathrm{O} 3$ $(0,58 \mathrm{wt} \%)$ dan $\mathrm{Fe} 2 \mathrm{O} 3(0,28 \mathrm{wt} \%)$. Phospate is chosen as a natural pore agent because of high organic content that possibility to remove synthetic additive to make pores [45-46].

\section{Flocculation and Ceramic Membrane Filtration}

Set one optimal operation condition is the important thing in membrane filtration that affected to filtration flux, permeate quality, and membrane fouling level [47]. In this research, the main operation condition is transmembrane pressure and cross-flow velocity [48]. The optimal flocculation condition is determined by orthogonal test from 4 factors. These factors have flocculant doses, mixing time, holding time after flocculation, and flocculation temperature. The Flocculant starts through the membrane for 120 minutes and using many times until decreasing pure flux approximately $20 \%$. After flocculant has been analyzed with oil extraction test then oil content from permeate analyzed with spectrophotometry UV [42].

4. The Strong Nanofibers PI Electrospol use as membrane matrix

Nanofiber PI membrane is making used electrospinning FM1206 [49]. Nuclear Magnetic Resonance Spectrum Proton is recorded using spectrometer Avance III HD $600 \mathrm{MHz}$ (Bruker BioSpin). Membrane structural properties are characterized by FT-IR. In particular, the absorbent spectrum has been recorded using spectrometer Nicolet 360 FT-IR with 32 scans on resolution $4 \mathrm{~cm}$ in approximately $400-4000 \mathrm{~cm}$. Membrane morphology is characterized by a transmission electron microscope (TEM) (JEM- 1400, JEOL, Japan) and field emission scanning electron microscope akuscrjpt FE-SEM (S-4800. Hitachi. Ltd, Japan). FE- SEM is featured by Energy Dispersive Spectrometer (EDS) [50].

\section{Membrane Premix SPG}

The SPG membrane hydrophilic and hydrophobic is provided by SPG Technology Co. Ltd (Miyazaki, Japan). The SPG membrane hydrophilic used for nano emulsion production Oil/Water and hydrophobic for nano emulsion Water/Oil. The first production of two membranes are the same, the hydrophobic membrane is obtained from the special layer making by the supplier. The membrane shape is a tube with inside diameter is $8.5 \mathrm{~mm}$, thickness $0.8 \mathrm{~mm}$, and length $125 \mathrm{~mm}$. In all of the test, the length of the membrane is $125 \mathrm{~mm}$ and the average pore size is $0.5 \mathrm{um}$. The membrane is able to maintain transmembrane pressure until 65 bar. Tubular module cross-flow adapted for PME. The effective membrane length is reduced because the seal ring placed on both of edge of the membrane tube. Therefore, the effective length is $115 \mathrm{~mm}$ and the effective large membrane is 30.7 
$\mathrm{cm}$. Before nano emulsion Oil/Water is used, the membrane is cleaned slowly until hydrodynamic resistant recovery to water $(\mathrm{Rm})$. For hydrodynamic resistant recovery measurement, water is absorbed through the membrane on the different flow between 10 and $200 \mathrm{~mL} /$ minutes and the pressure result noted. Rm predictively from water flow slop Vs the resulting pressure [44]. The cleaning procedure is divided into three injections through membrane $500 \mathrm{~mL}$ Derquim solution + $1 \%$ on $70^{\circ} \mathrm{C} 200 \mathrm{~mL} /$ minutes and then three injections $500 \mathrm{~mL}$ pure water in room temperature and $200 \mathrm{~mL} /$ minutes. Membrane resistance on water recover after this treatment. For nano emulsion Water/Oil, the membrane is cleaned slowly with Span 80 in Marcol 82 until pure recovery and stability pressure. Fill membrane with oil maybe make an emulsion flow easier through the membrane [53].

\section{Organoclay}

Organoclay is the water treatment method with hydrocarbon solvent removals like benzene, toluene, ethylbenzene, and xylene (BTEX) [54-55]. Before organoclay released, GAC (Granular Active Carbon) is the standard treatment. However, organoclay has superiority than GAC that is a high absorption of HC solvent, then used media from this method is not be a dangerous waste [32].

\section{Carbon Nanotubes (CNT)}

This research us using two types CNT: Commercial CNT and Produced CNT. The average diameter from CNT approximately between $20-50 \mathrm{~nm}$ [3]. The same method but has a different ingredient. Before doing the removal hydrophobic non-woven is soaked in OTS (Octadecysilane) for 12 hours. Then, add hydrophobic non-woven into the fluid that contains emulsion oil-water [56]. There are some methods are same origins like nanocomposites from chemical material $\mathrm{Fe} 3 \mathrm{O} 4 / \mathrm{SiO} 2$, $\mathrm{Fe} 3 \mathrm{O} 4 / \mathrm{TiO} 2$, and $16 \mathrm{Fe} 3 \mathrm{O} 4 /$ Chitosan nanocomposites [57], superhydrophobic nanodiamonds method is added hydroxyl, generally, it has the same procedures like nanotubes, however, nanodiamonds using alkaline liquid ( $\mathrm{PH}$ 8.5) [58], nanofibrous method combine with electrospun fibres, it used to reduce wettability value from oil so that easier in removal [59].

\section{Combination with Synthetic Polymer}

Membrane method with responsible polymer fibre has been moistened with water that has $\mathrm{pH}$ 3 (acid). Then, membrane fibre has a pore size $9 \mu \mathrm{m}$ [60], mesh film covered by $\mathrm{ZnO}$ and then heated with temperature $420 \mathrm{C}$. It aims to minimize film pore, nanorod $\mathrm{ZnO}$ has a pore diameter $50 \mu \mathrm{m}$ [61], amorphous carbon thin film (ACTF) membrane has organic fibre, it makes from palm leaf (OPL) [62], using nanofiltration to remove but oleophobic membrane is used [63], using membrane that mixed with polytetrafluoroethylene (PTFE) [64].

\section{Coagulation}

Coagulation and foam removal using casein has shown high potential as an alternative method to dissolve air flotation to process emulsion water oil. When controlled casein dose in a good coagulation condition, $96-99 \%$ oil removal perhaps for wastewater. The result shows that remaining oil in the water can reach a concentration of less than $5 \mathrm{mg} / \mathrm{L}$ [65-66].

\section{Centrifuge Test, Hydro Cyclone, Membrane, and Corrosion Inhibitor}

Centrifuge test may help to reduce the oil content in produced water below $10 \mathrm{mg} / \mathrm{L}$. For Hydro Cyclone test is not effective to reduce the oil content in produced water meanwhile from the four membranes have been tested, filtration micro hydrophilic membrane shows the best capacity behaviour slowly and vulnerability to fouling. Even in the high oil concentration, the membrane can remove oil condensate droplet from water. Inhibitor test that injected in the optimal level is succeeded significantly to reduce oil content from produced water until $12 \mathrm{mg} / \mathrm{L}$ and reduce corrosion effect from carbonate acid that exists in water [22]. 


\section{Gravity Separation}

Removal with gravitation rock is the first common step to do using the tool like gravity separator, API separator and skim tank. the effects of this method depending on retention time design, fluid properties and addition additive to accelerate the removal [6][67].

\section{Demulsification}

In this case, Pretreatment exists with three steps to do periodically. There is sedimentation, oil removal with demulsification, and flotation removal. Fixing oil and water emulsion also can use as an EOR method in waterflood like Iranian Oilfield. However, in this case, is needed to add packing flooding test HP-HT [68].

\section{Electrochemical}

The technique based on electrochemical is developing from electrode material and be a widely applied electro. Inorganic salt removal from water, heavy metal, acid radical, and remove organic pollution in the certain colloid particle [69[. The electrochemical technique has been used to recycle the fluid and inferior solid in the fluid can remove without chemical addition [70].

\section{Filtration Using Granular Media}

One of the waste oil sources is the oil refinery. Environment pollution occurs during production, transportation, purification activities. Filter media walnut shell is made using sieve analysis under the ASTM D422-63. It used compression method [71]. There is a lot of problem in industry activity about removal wastewater contain emulsion. It used kenaf filter media [72]. Conventionally filtration using sand that has been leaving with granular media usage like peanut shells [73]. The method has been used to experiment with the sample in the laboratory, an oil sample is taken from Al-Duara refinery and batch test laboratory is mixing [74]. Amount of produced water from oilfield is needed to do the wastewater treatment. Deep-bed filtration is a good technology to removal process between water and oil. Using plant fibre as a filtrate media is recommended. Sunflower pith test using SEM and FTIR spectroscopy [46] [75-76]. The test of absorption efficiency using filter media [77]. The last phase is marked by produced water for more than $90 \%$. This produced water is an expensive process and usually prepared for water injection [6].

\section{Results}

\section{Absorption}

Using three composite biopolymer hybrid so that absorption efficiency is different. Because this thing is affected by contact time, $\mathrm{pH}$, dose, initial oil concentration, and temperature itself. The result shows oil absorption is 91, 82 and 45\% (La@ CS-GEL, Zr @ CS-GEL dan Ce @ CS-GEL [23]. The absorption capacity approximately from 4 to $34 \mathrm{~g}$ for various oil type, because of hydrophobic is able selectively removal oil from water and the absorption process is faster, it can use 20 times [24]. Addition rGo in natural rubber increases oil absorption capacity more than $70 \%$ after 30 times used [25]. After doing the test with 3 different cycles, it gets removal efficiency $98 \%, 95 \%$, and $91 \%$ [26].

\section{Gas Flotation}

The higher aluminium sulphate concentration, the lower oil residual concentration in water with effectiveness $88 \%$. Oil removal percentage also get from water to oil ratio. Maximum rate will be reached when potential ZETA is 0 . The result of heavy polymer is hydracoll 882 and 864 tend to a positive value meanwhile the light polymer is vice versa. In general, DAF tool performance will be escalation with improving working pressure [28]. The time of oil to absorb is increased when added the coal to the DAF process meanwhile the effect of coal size is the bigger the size, the bigger the economics with the maximal size is $2046 \mu \mathrm{m}$.

With additives like dimethylacetamide (DMAC) will get the recovery until $100 \%$. Other than that, with flocculation filtration tool will increment water cleaning efficiency [81-82]. 


\section{Cyclones Separation}

With this system, the efficiency is $90 \%$. This method is on GLR optimal area $9-10 \%$ [32].

\section{Membrane}

The double functional membrane covered by PDA/PEPA/SH at the same time can remove oil from water and absorb mercury ion that soluble in the water. It can use many times and maintain removal efficiency that able to reduce operation cost [43]. The ceramic membrane produces crossflow velocity through the membrane in $0.6-1.3 \mathrm{~m} / \mathrm{s}$. The permeate flux is various from 3.4 to $3300 \mathrm{~L} /$ (h $\mathrm{m} 2$ bar). UF membrane is used and increase oil removal until 99\% [83]. According to the Hoslett et al., (2018) produce resin composite that prepared efficiently than CIE, PC, and porosity. This thing is confirmed the performance to absorb crude oil from contaminated water. If using $10 \mathrm{~g}$ resin composite for the treatment of $1000 \mathrm{~mL}$ PPW, oil removal $99 \%$ has been reached where oil concentration decreases from 148.5 to $1.13 \mathrm{~g} / \mathrm{L}$. Because of PPW treatment, the consequence of it is microfiltration on a laboratory scale.

Flat ceramic microfiltration membranes are prepared at $1100{ }^{\circ} \mathrm{C}$ through a uniaxial dry compaction process by mixing pure Moroccan natural minerals red clay and natural phosphate. Natural phosphates are capable of producing porous structures. The effect of adding natural phosphate (weight $10-40 \%$ ) on the microstructure and mechanical properties was evaluated. The microfiltration performance of selected ceramic membranes was examined experimentally with various feed variations. Based on this study, SEM analysis results revealed that the structure is more porous for membrane membranes containing $40 \%$ by weight NPh compared to 10 and $20 \%$ by weight. The main pore size is around $2.5 \mu \mathrm{m}$. A significant decrease in flexural strength from 37.44 to 17.5 MPa was observed with an increase in the amount of natural phosphate due to increased porosity. The optimal mass ratio of clay/phosphate is confirmed as 3: 2 . The optimal ceramic membrane has a thermal expansion coefficient of less than $13.42 \times 10-6^{\circ} \mathrm{C}-1$, high thermal shock resistance up to $1100^{\circ} \mathrm{C}$, good flexural strength $(17.72 \mathrm{MPa})$, strong alkali corrosion resistance and good permeability of $928 \mathrm{~L} /(\mathrm{h} \cdot \mathrm{m} 2 \cdot$ bar). Support shows an increase in turbidity removal efficiency for Fe wooden tannery waste $(99.80 \%)$, raw seawater $(99.62 \%)$ and synthetic salt water $(99.86 \%)$ [45].

In the study confirmed the use of ceramic membranes for the separation of fermentation broths. Done with broth, which is prepared using Citrobacter freundii bacteria. A tight tubular ultrafiltration ceramic membrane $(8 \mathrm{kD})$ was applied and complete rejection of bacteria and other suspended solids was achieved. The resulting seepage is clear, with turbidity at the level of 0.1 NTU which makes it possible to use the solution for further separation in the nanofiltration process by using spiral-wound modules. Separation of the glycerol solution fermented by bacteria revealed that a continuous decrease in flux occurred during ultrafiltration of broth with a ceramic UF membrane. After the initial rapid decrease of permeate flux, the quasi-constant period of filtration rate is observed, at a maximum level of 0.2-0.3 permeating the flux. The application of $20-30$ minutes module flushing with $\% 1 \%$ $\mathrm{NaOH}$ solution is permitted to efficiently remove contamination from the membrane, even after three days of exploitation. The application of the ultrafiltration process for the treatment of solutions with metabolites formed from bacteria is permitted to be obtained at an increase of $30-40 \%$ from the biosynthesis of 1,3-PD from glycerol [68]. In the case of organoclay used in combination with GAC. Organoclay itself is produced by combining montmorillonite sodium clay with cationic quaternary amine salts as organic pillar removers between clay platelets which increase distance and as a facilitator of $\mathrm{HC}$ formation. With this method, the results show that BTEX removal rates range from Benzene $27 \%$, Toluene $58 \%$, Ethylbenzene $72 \%$ and Xylene $71 \%$ [32].

To determine the efficiency level of CNT absorption, a thermogravimetric analysis is used to measure the maximum absorption rate of CNT where the results are obtained for $\mathrm{P}-\mathrm{CNT}=97 \%$ and $\mathrm{C}-\mathrm{CNT}=87 \%$, in the method of hydrophobic non-woven fabric by adding OTS (octadecylsilane) chemicals to increased oil absorption from water by $7.2 \mathrm{~g} / \mathrm{l}$, which is the highest yield compared to the nanofibers method. In terms of emulsion stability, microscopically showed that all nanocomposites synthesized had better performance in stabilizing emulsion separation. IFT 
(interfacial tension) measurements showed a decrease of $18-21 \mathrm{mN} / \mathrm{m}$, with a decrease in the value of IFT showing that the separation process was successfully used by adding nanocomposite to oilwater emulsions [57]. Superhydrophobic nanodiamonds get an efficiency of $76 \%$, not too large compared to other methods, but there are advantages over other methods, which are lower cost and good stability and performance [86], nanofiber methods combined with electrospun can increase efficiency up to $99 \%$.

By using membranes that have different types have succeeded in separating oil-water from liquid paraffin, diesel oil. From several membrane methods, it is obtained an efficiency level of $>90 \%$ and has the advantage of being used for a long period [64]. In general, the process of absorption or separation of oil is influenced by several phases such as contact time, oil concentration in an emulsion [87].

\section{Coagulation}

Flocculation can reduce oil content and COD value from wastewater contains mud. The optimal flocculant is 3530 S derivative of polyacrylamide. The flocculation condition is flocculant dose, mixing time, and holding time after mixing. It needs optimum condition, that is $70 \mathrm{mg}$ dose, mixing time is 90 minutes, and holding time 90 minutes too. The permeate quality after flocculation with $3530 \mathrm{~S}$ and MF using $0.2 \mu \mathrm{m} \mathrm{ZrO2} \mathrm{membrane} \mathrm{is} \mathrm{better} \mathrm{than} \mathrm{MF} \mathrm{and} \mathrm{required} \mathrm{to} \mathrm{National} \mathrm{Discharge} \mathrm{Standard}$ [82]. Potential oil removal in the water from some membranes is analyzed using some mixing oil models, the membrane has a high flux, removal efficiency, and able to reuse. From this research [88], nano emulsion O/W and W/O are prepared successfully by PME membrane and SPG [49]. Because of the pressure must lower than 65 bar through the membrane, we have to analyzed viscosity effect, dispersion phase, and different phase content to get to produce viscous nano emulsion $\mathrm{O} / \mathrm{W}$ and $\mathrm{W} / \mathrm{o}$ successfully.

\section{Demulsification}

More than $95 \%$ of oil is obtained from wastewater that required to conventional treatment. This is verified and the treatment process is for $60 \mathrm{t} /$ hours [68][89].

\section{Electrochemical}

This method successfully removes the inferior solid after wastewater sample has been produced with electrochemical. In India, it has a positive impact on them [90][70].

\section{Filtration Using Granular Media}

This method shows absorb capacity of $0.3 \mathrm{~g} / \mathrm{g}$. DoALL sample has absorbed capacity of $0.58 \mathrm{~g} / \mathrm{g}$ produced absorb capacity of $0.74 \mathrm{~g} / \mathrm{g}$ [71]. The method carried out by filtration experiments using kenaf filter media produces about 70 to $95 \%$ can be achieved removing oil and fat in wastewater 500 $\mathrm{mg} / \mathrm{L}$ with surfactant stabilizers [72]. Up to $96 \%$ oil removal from artificial samples is achieved while test results show that $75 \%$ of oil can be removed from the actual wastewater released from the AlDuara refinery south of Baghdad [74]. The level of filtration efficiency using sunflower pith media to oil from production water is almost $99 \%$ [77]. In offshore fields using HC, IGF and CFU technology is the best choice. Combining with NSF and CMF technology can provide efficiencies that will be more beneficial [1]. Based on the results obtained, papyrus reeds are effective and efficient for removing oil and can be significantly used as an inexpensive and environmentally friendly adsorbent for the treatment of water produced. Good results by the Freundlich method with experimental data $\mathrm{n}<1$ which showed favourable adsorbs. Also, if the concentration is increased to $5000 \mathrm{ppm}$ from 1000 ppm the percentage of oil removal will be $87.6 \%$ from $50.8 \%$ [7]. Feasibility test of RO and UF membranes for multi-benefit use of produced water. This mechanism produces effective performance from MDU and filter. The cost of treating treated water is cheaper $(\$ 0.775 /$ barrel) than removing it 
by injection ( $\$ 0.75-8$ / barrel) and this treated water may be of high value in water-poor areas. Based on several tested parameters showing the feasibility of water after three stages of processing. For example for the potential application of membrane-treated water for agricultural irrigation, it is necessary to consider the level of product water conductivity and the concentration of sodium, calcium, and magnesium ions and for drinking water standards (500 mg / L TDS) and irrigation water standards (1,000 mg / L TDS) meet the requirements [78]. Structured management is needed to meet water management requirements in meeting applicable environmental regulations. Reinjection of water to the formation and aquifers is more widely used. The biggest concern problem is the injection reduction due to the injection process and needs to ensure long-term injection to prevent it [6].

\section{Conclusions}

There are so many methods have been used in water treatment or oil absorption. It has advantages and disadvantages:

- Adsorption method shows higher efficiency because of the simple process, friendly environment, low operational cost, and easy recovery absorption.

- In cyclone separation, Double Cone Air Sparged Hydro clone (DcASH) method is an effective way to increase water quality on polymer flood.

- Membrane technology has been the main component in schematic water reclamation. It can provide high water quality and low cost.

- Coagulation and foam removal using casein shows high potential as an alternative method to Dissolve Air Flotation (DAF) to process emulsion water oil.

- The hydrophilic microfiltration membrane shows the best capacity of behaviour slowly and vulnerability to fouling. Even in the high oil concentration, the membrane can remove oil condensate droplet from water.

To do water treatment is need a required technology. Choosing technology based on chemical content in the water, cost efficiency, space, process planning, operation time, and additional product. Even the water is poisonous, it can be used safely for injection, drinking water, and a country lacks water. It caused by the right technology is choosing.

Author Contributions: Conceptualization, B.S., R.A. and M.R.A.; methodology, A.N.E. and A.F.; validation, M. and R.A.; writing-original draft preparation, W.R. and M.F; writing-review and editing, W.R.; visualization, W.R.; supervision, M.K.A. and T.E.; project administration, W.R.

Funding: This review received no external funding

Acknowledgments: This review was supported by the cooperation of 9 people as an author and 2 people as a supervision (M.K.A and T.E.)

Conflicts of Interest: The authors declare no conflict of interest.

\section{References}

[1] S. Judd et al., "The size and performance of offshore produced water oil-removal technologies for reinjection," Sep. Purif. Technol., vol. 134, hal. 241-246, 2014.

[2] T. D. Kusworo, N. Aryanti, Qudratun, dan D. P. Utomo, “Oilfield produced water treatment to clean water using integrated activated carbon-bentonite adsorbent and double stages membrane process," Chem. Eng. J., vol. 347, no. April, hal. 462-471, 2018.

[3] H. Albatrni, H. Qiblawey, F. Almomani, S. Adham, dan M. Khraisheh, "Polymeric adsorbents for oil removal from water," Chemosphere, vol. 233, hal. 809-817, 2019.

[4] A. Motta, C. Borges, K. Esquerre, dan A. Kiperstok, “Oil Produced Water treatment for oil removal by an integration of coalescer bed and microfiltration membrane processes," J. Memb. Sci., vol. 469, hal. 371-378, 2014.

[5] E. L. Hagström, C. Lyles, M. Pattanayek, B. DeShields, dan M. P. Berkman, “Produced Water-Emerging 
Challenges, Risks, and Opportunities," Environ. Claims J., vol. 28, no. 2, hal. 122-139, Apr 2016.

[6] S. Nesic dan V. V Streletskaya, “An integrated approach for produced water treatment and injection," Гeopecypcbl, vol. 20, no. 1 (eng), 2018.

[7] F. AL-Zuhairi et al., "Removal oil from produced water by using adsorption method with adsorbent a Papyrus reeds," Eng. Technol. J., vol. 37, no. 05, hal. 157-165, 2019.

[8] J. Fan, E. N. Sappington, H. S. Rifai, dan D. F. Rodrigues, “Confocal microscopy as a new real-time quantification method for oil content in produced water," J. Pet. Sci. Eng., vol. 167, no. March, hal. 54-63, 2018.

[9] R. W. Paige, L. R. Murray, J. P. Martins, dan S. M. Marsh, “Optimising Water Injection Performance,” SPE Repr. Ser., no. 56, hal. 173-181, 2003.

[10] Y. S. Li, L. Yan, C. B. Xiang, dan L. J. Hong, “Treatment of oily wastewater by organic-inorganic composite tubular ultrafiltration (UF) membranes," Desalination, vol. 196, no. 1-3, hal. 76-83, 2006.

[11] S. Jiménez, M. M. Micó, M. Arnaldos, F. Medina, dan S. Contreras, "State of the art of produced water treatment," Chemosphere, vol. 192, hal. 186-208, 2018.

[12] A. A. Yousef, S. Al-Saleh, dan M. Al-Jawfi, “Improved/enhanced oil recovery from carbonate reservoirs by tuning injection water salinity and ionic content," Proc. - SPE Symp. Improv. Oil Recover., vol. 1, hal. 819-836, 2012.

[13] H. I. Abdel-Shafy dan S. H. Abdel-Shafy, "Membrane technology for water and wastewater management and application in Egypt," Egypt. J. Chem., vol. 60, no. 3, hal. 347-360, 2017.

[14] M. Duan et al., "A novel interface-active cationic flocculant for the oil-water separation of oily wastewater produced from polymer flooding," J. Mol. Liq., vol. 286, hal. 110868, 2019.

[15] K. M. Bansal dan D. D. Caudle, "Interferences with produced water treatment for dispersed oil removal," Soc. Pet. Eng. - SPE Int. Conf. Heal. Safety, Environ. Oil Gas Explor. Prod. 1998, HSE 1998, no. c, 1998.

[16] H. I. Abdel-Shafy, M. S. M. Mansour, dan M. M. El-Toony, “Integrated treatment for oil free petroleum produced water using novel resin composite followed by microfiltration," Sep. Purif. Technol., vol. 234, no. July 2019, hal. 116058, 2020.

[17] S. Park, E. S. Lee, dan W. R. W. Sulaiman, “Adsorption behaviors of surfactants for chemical flooding in enhanced oil recovery," J. Ind. Eng. Chem., vol. 21, hal. 1239-1245, 2015.

[18] Q. Zhang et al., "A facile method to prepare dual-functional membrane for efficient oil removal and in situ reversible mercury ions adsorption from wastewater," Appl. Surf. Sci., vol. 434, hal. 57-62, 2018.

[19] S. A. Kevin Gunawan, M. Saekhu, Renindra A. Aman, Syaiful Ichwan, Setyo Widi Nugroho, Hanif G. Tobing, “Visual Function Impairment in Sellar Region Tumors: An Initial Study," vol. 4, no. November, hal. 1-3, 2012.

[20] W. Kang et al., "The effect of stepwise increasing of water injection rates on enhanced oil recovery after preformed particle gel treatment," J. Pet. Sci. Eng., vol. 182, no. March, hal. 106239, 2019.

[21] C. A. Franco, N. N. Nassar, dan F. B. Cortés, “Removal of oil from oil-in-saltwater emulsions by adsorption onto nano-alumina functionalized with petroleum vacuum residue," J. Colloid Interface Sci., vol. 433, hal. 58-67, 2014.

[22] F. J. op ten Noort, J. P. Etten, dan R. S. Donders, "Reduction of residual oil content in produced water at offshore gas production platform P/6A," Eur. Pet. Conf., vol. 1, hal. 9-18, 1990.

[23] S. S. Elanchezhiyan, S. M. Prabhu, dan S. Meenakshi, "Effective adsorption of oil droplets from oil-in-water emulsion using metal ions encapsulated biopolymers: Role of metal ions and their mechanism in oil removal," Int. J. Biol. Macromol., vol. 112, hal. 294-305, 2018.

[24] S. Sabir, "Approach of cost-effective adsorbents for oil removal from oily water," Crit. Rev. Environ. Sci. Technol., vol. 45, no. 17, hal. 1916-1945, 2015.

[25] S. Songsaeng, P. Thamyongkit, dan S. Poompradub, "Natural rubber/reduced-graphene oxide composite materials: Morphological and oil adsorption properties for treatment of oil spills," J. Adv. Res., vol. 20, hal. 79-89, 
2019.

[26] H. H. El-Maghrabi, R. Hosny, M. Ramzi, M. A. Zayed, dan M. Fathy, “Preparation and Characterization of Novel Magnetic ZnFe2O4-Hydroxyapatite Core-Shell Nanocomposite and Its Use as Fixed Bed Column System for Removal of Oil Residue in Oily Wastewater Samples," Egypt. J. Pet., vol. 28, no. 2, hal. 137-144, 2019.

[27] R. Zolfaghari, A. Fakhru'l-Razi, L. C. Abdullah, S. S. E. H. Elnashaie, dan A. Pendashteh, “Demulsification techniques of water-in-oil and oil-in-water emulsions in petroleum industry," Sep. Purif. Technol., vol. 170, hal. 377-407, 2016.

[28] A. A. Al-Shamrani, A. James, dan H. Xiao, "Separation of oil from water by dissolved air flotation," Colloids Surfaces A Physicochem. Eng. Asp., vol. 209, no. 1, hal. 15-26, 2002.

[29] A. Motta, C. Borges, K. Esquerre, dan A. Kiperstok, “Oil Produced Water treatment for oil removal by an integration of coalescer bed and microfiltration membrane processes," J. Memb. Sci., vol. 469, hal. 371-378, 2014.

[30] X. Li, C. Zhang, dan J. Liu, “Adsorption of oil from waste water by coal: Characteristics and mechanism," Min. Sci. Technol., vol. 20, no. 5, hal. 778-781, 2010.

[31] A. S. Santos, L. F. S. Oliveira, A. M. T. Marques, D. C. A. Silva, dan C. R. E. Mansur, “Evaluation of the efficiency of polyethylenimine as flocculants in the removal of oil present in produced water," Colloids Surfaces A Physicochem. Eng. Asp., vol. 558, hal. 200-210, 2018.

[32] S. Liu, X. Zhao, X. Dong, B. Miao, dan W. Du, "Treatment of produced water from polymer flooding process using a new type of air sparged hydrocyclone," 2005 SPE Asia Pacific Heal. Saf. Environ. Conf. Exhib. - Proc., vol. 2005, hal. 49-52, 2005.

[33] S. Deng et al., "Produced water from polymer flooding process in crude oil extraction: Characterization and treatment by a novel crossflow oil-water separator," Sep. Purif. Technol., vol. 29, no. 3, hal. 207-216, 2002.

[34] Y.S. Li, L. Yan, C. B. Xiang, dan L. J. Hong, "Treatment of oily wastewater by organic-inorganic composite tubular ultrafiltration (UF) membranes," Desalination, vol. 196, no. 1, hal. 76-83, 2006.

[35] M. Cheryan dan N. Rajagopalan, "Membrane processing of oily streams. Wastewater treatment and waste reduction," J. Memb. Sci., vol. 151, no. 1, hal. 13-28, 1998.

[36] J. M. Lee dan T. Frankiewicz, "Treatment of produced water with an ultrafiltration (UF) membrane - A field trial," Proc. - SPE Annu. Tech. Conf. Exhib., hal. 1363-1368, 2005.

[37] I.-S. Chang, C.-M. Chung, dan S.-H. Han, "Treatment of oily wastewater by ultrafiltration and ozone," Desalination, vol. 133, no. 3, hal. 225-232, 2001.

[38] F. Li, X. Wu, J. Wu, X. Xu, dan S. Ma, "Kinetic study of adsorption of oil from oilfield produced water using modified porous ceramics filtration media in column mode," 2nd Int. Conf. Bioinforma. Biomed. Eng. iCBBE 2008, hal. 2745-2748, 2008.

[39] A. Kayvani Fard, G. Mckay, Y. Manawi, Z. Malaibari, dan M. A. Hussien, “Outstanding adsorption performance of high aspect ratio and super-hydrophobic carbon nanotubes for oil removal," Chemosphere, vol. 164, hal. 142$155,2016$.

[40] R. Bhave, Inorganic Membranes Synthesis, Characteristics and Applications: Synthesis, characteristics, and applications. Springer Netherlands, 2012.

[41] P. E. King, “Maureen produced water injection," Offshore Eur. 93, hal. 275-283, 1993.

[42] K. Katika et al., "Comparative analysis of experimental methods for quantification of small amounts of oil in water," J. Pet. Sci. Eng., vol. 147, hal. 459-467, 2016.

[43] D. Tian et al., "Photo-induced water-oil separation based on switchable superhydrophobicitysuperhydrophilicity and underwater superoleophobicity of the aligned $\mathrm{ZnO}$ nanorod array-coated mesh films," J. Mater. Chem., vol. 22, no. 37, hal. 19652-19657, 2012. 
[44] M. N. Chollom, K. Pikwa, S. Rathilal, dan V. L. Pillay, "Fouling mitigation on a woven fibre microfiltration membrane for the treatment of raw water," South African J. Chem. Eng., vol. 23, hal. 1-9, 2017.

[45] M. Mouiya et al., "Flat ceramic microfiltration membrane based on natural clay and Moroccan phosphate for desalination and industrial wastewater treatment," Desalination, vol. 427, no. November 2017, hal. 42-50, 2018.

[46] S. E. Weschenfelder, M. J. C. Fonseca, B. R. S. Costa, dan C. P. Borges, “Influence of the use of surfactants in the treatment of produced water by ceramic membranes," J. Water Process Eng., vol. 32, no. July, hal. 100955, 2019.

[47] P. . Ramesh R. Bhave, INORGANIC MEMBRANES SYNTHESIS, CHARACTERISTICS AND APPLICATIONS. 1991.

[48] J. Zhong, X. Sun, dan C. Wang, "Treatment of oily wastewater produced from refinery processes using flocculation and ceramic membrane filtration," Sep. Purif. Technol., vol. 32, no. 1, hal. 93-98, 2003.

[49] W. Ma et al., "Dual pH- and ammonia-vapor-responsive electrospun nanofibrous membranes for oil-water separations," J. Memb. Sci., vol. 537, hal. 128-139, 2017.

[50] G. da Costa Cunha, N. C. Pinho, I. A. Alves Silva, J. A. Santana Costa, C. M. P. da Silva, dan L. P. C. Romão, “Removal of heavy crude oil from water surfaces using a magnetic inorganic-organic hybrid powder and membrane system," J. Environ. Manage., vol. 247, no. August 2018, hal. 9-18, 2019.

[51] G. T. Vladisavljević, M. Shimizu, dan T. Nakashima, "Permeability of hydrophilic and hydrophobic Shirasuporous-glass (SPG) membranes to pure liquids and its microstructure," J. Memb. Sci., vol. 250, no. 1-2, hal. 69-77, 2005.

[52] S. H. D. Silalahi dan T. Leiknes, "Cleaning strategies in ceramic microfiltration membranes fouled by oil and particulate matter in produced water," Desalination, vol. 236, no. 1, hal. 160-169, 2009.

[53] G. T. Vladisavljević dan H. Schubert, "Influence of process parameters on droplet size distribution in SPG membrane emulsification and stability of prepared emulsion droplets," J. Memb. Sci., vol. 225, no. 1-2, hal. 15-23, 2003.

[54] D. H. Doyle dan A. B. Brown, "Produced water treatment and hydrocarbon removal with organoclay," SPE Annu. Tech. Conf. Proc., no. PI, hal. 501-512, 2000.

[55] M. A. Al-Kaabi, M. A. Al-Ghouti, M. Y. M. Ashfaq, T. Ahmed, dan N. Zouari, "An integrated approach for produced water treatment using microemulsions modified activated carbon," J. Water Process Eng., vol. 31, no. April, hal. 100830, 2019.

[56] X. Zhu, X. Wang, Y. Liu, Y. Tian, dan Y. Li, “Efficient adsorption of oil in water by hydrophobic nonwoven fabrics coated with cross-linked polydivinylbenzene fibers," J. Chem. Technol. Biotechnol., vol. 94, no. 1, hal. 128-135, 2019.

[57] H. Rezvani, Y. Kazemzadeh, M. Sharifi, M. Riazi, dan S. Shojaei, "A new insight into Fe3O4-based nanocomposites for adsorption of asphaltene at the oil/water interface: An experimental interfacial study," J. Pet. Sci. Eng., vol. 177, hal. 786-797, 2019.

[58] N. Cao, B. Yang, A. Barras, S. Szunerits, dan R. Boukherroub, "Polyurethane sponge functionalized with superhydrophobic nanodiamond particles for efficient oil/water separation," Chem. Eng. J., vol. 307, hal. 319-325, 2017.

[59] X. Wang, J. Yu, G. Sun, dan B. Ding, “Electrospun nanofibrous materials: a versatile medium for effective oil/water separation," Mater. Today, vol. 19, no. 7, hal. 403-414, 2016.

[60] J. J. Li, Y. N. Zhou, dan Z. H. Luo, "Smart Fiber Membrane for pH-Induced Oil/Water Separation," ACS Appl. Mater. Interfaces, vol. 7, no. 35, hal. 19643-19650, 2015.

[61] D. Tian et al., "Photo-induced water-oil separation based on switchable superhydrophobicitysuperhydrophilicity and underwater superoleophobicity of the aligned $\mathrm{ZnO}$ nanorod array-coated mesh films," J. Mater. Chem., vol. 22, no. 37, hal. 19652-19657, 2012. 
[62] M. Fathy, M. El-Sayed, M. Ramzi, dan O. H. Abdelraheem, “Adsorption separation of condensate oil from produced water using ACTF prepared of oil palm leaves by batch and fixed bed techniques," Egypt. J. Pet., vol. 27, no. 3, hal. 319-326, 2018.

[63] E. Park dan S. M. Barnett, "Oil/water separation using nanofiltration membrane technology," Sep. Sci. Technol., vol. 36, no. 7, hal. 1527-1542, 2001.

[64] H. Unno, H. Saka, dan T. Akehata, "Oil separation from oil-water mixture by a porous poly (tetrafluoroethylene)(PTFE) membrane," J. Chem. Eng. Japan, vol. 19, no. 4, hal. 281-286, 1986.

[65] Y. Suzuki dan T. Maruyama, "Removal of emulsified oil from water by coagulation and foam separation," Sep. Sci. Technol., vol. 40, no. 16, hal. 3407-3418, 2005.

[66] A. Almojjly, D. Johnson, D. L. Oatley-Radcliffe, dan N. Hilal, “Removal of oil from oil-water emulsion by hybrid coagulation/sand filter as pre-treatment," J. Water Process Eng., vol. 26, no. July, hal. 17-27, 2018.

[67] Heba H. El-Maghrabi, R. Hosny, M. Ramzi, M. A. Zayed, dan M. Fathy, "Preparation and Characterization of Novel Magnetic ZnFe2O4-Hydroxyapatite Core-Shell Nanocomposite and Its Use as Fixed Bed Column System for Removal of Oil Residue in Oily Wastewater Samples," Egypt. J. Pet., vol. 28, no. 2, hal. 137-144, 2019.

[68] E. Yazdani Sadati dan E. Sahraei, "An experimental investigation on enhancing water flooding performance using oil-in-water emulsions in an Iranian oil reservoir," J. Pet. Explor. Prod. Technol., vol. 9, no. 4, hal. 2613-2624, 2019.

[69] S. Xie et al., "An electrochemical adsorption method for the reuse of waste water-based drilling fluids," Nat. Gas Ind. B, vol. 5, no. 5, hal. 508-512, 2018.

[70] H. Roshan, S. Ehsani, C. E. Marjo, M. S. Andersen, dan R. I. Acworth, "Mechanisms of water adsorption into partially saturated fractured shales: An experimental study," Fuel, vol. 159, hal. 628-637, 2015.

[71] A. Srinivasan dan T. Viraraghavan, "Removal of oil by walnut shell media," Bioresour. Technol., vol. 99, no. 17, hal. 8217-8220, 2008.

[72] B. K. Varghese dan T. G. Cleveland, "Kenaf as a deep-bed filter medium to remove oil from oil-in-water emulsions," 1998.

[73] Z. Zhang, X. Du, K. H. Carlson, C. A. Robbins, dan T. Tong, "Effective treatment of shale oil and gas produced water by membrane distillation coupled with precipitative softening and walnut shell filtration," Desalination, vol. 454, no. December 2018, hal. 82-90, 2019.

[74] Z. Z. Ismail, "Removal of Oil From Wastewater Using," Al-Khwarizmi Eng. J., vol. 1, no. 1, hal. 117-124, 2005.

[75] M. Sharma et al., "Efficient oil removal from wastewater based on polymer coated superhydrophobic tetrapodal magnetic nanocomposite adsorbent," Appl. Mater. Today, vol. 17, hal. 130-141, 2019.

[76] N. T. V. M. M. Dorfman, “FROM THE USINSK OIL FIELD BY IR-SPECTROSCOPIC,” no. October, hal. 5-8, 1993.

[77] E. Knapik dan J. Stopa, “Fibrous deep-bed filtration for oil/water separation using sunflower pith as filter media," Ecol. Eng., vol. 121, hal. 44-52, 2018.

[78] R. Kohlheb, “Water treatment technology for produced water," 2010.

[79] Y. S. Li, L. Yan, C. B. Xiang, dan L. J. Hong, “Treatment of oily wastewater by organic-inorganic composite tubular ultrafiltration (UF) membranes," Desalination, vol. 196, no. 1-3, hal. 76-83, 2006.

[80] M. Masuelli, J. Marchese, dan N. A. Ochoa, "SPC/PVDF membranes for emulsified oily wastewater treatment," J. Memb. Sci., vol. 326, no. 2, hal. 688-693, 2009.

[81] A. A. Al-Shamrani, A. James, dan H. Xiao, "Separation of oil from water by dissolved air flotation," Colloids Surfaces A Physicochem. Eng. Asp., vol. 209, no. 1, hal. 15-26, 2002.

[82] J. Zhong, X. Sun, dan C. Wang, "Treatment of oily wastewater produced from refinery processes using flocculation and ceramic membrane filtration," Sep. Purif. Technol., vol. 32, no. 1-3, hal. 93-98, 2003.

[83] M. Ebrahimi et al., "Characterization and application of different ceramic membranes for the oil-field produced 
water treatment," Desalination, vol. 245, no. 1-3, hal. 533-540, 2009.

[84] J. Hoslett et al., “Surface water filtration using granular media and membranes: A review," Sci. Total Environ., vol. 639, hal. 1268-1282, 2018.

[85] M. Waszak dan M. Gryta, "The ultrafiltration ceramic membrane used for broth separation in membrane bioreactor," Chem. Eng. J., vol. 305, hal. 129-135, 2016.

[86] N. Cao, B. Yang, A. Barras, S. Szunerits, dan R. Boukherroub, "Polyurethane sponge functionalized with superhydrophobic nanodiamond particles for efficient oil/water separation," Chem. Eng. J., vol. 307, hal. 319-325, 2017.

[87] A. Kayvani Fard, G. Mckay, Y. Manawi, Z. Malaibari, dan M. A. Hussien, “Outstanding adsorption performance of high aspect ratio and super-hydrophobic carbon nanotubes for oil removal," Chemosphere, vol. 164, hal. 142$155,2016$.

[88] O. Alliod, L. Messager, H. Fessi, D. Dupin, dan C. Charcosset, "Influence of viscosity for oil-in-water and waterin-oil nanoemulsions production by SPG premix membrane emulsification," Chem. Eng. Res. Des., vol. 142, hal. 87-99, 2019.

[89] C. Chen, G. Yan, S. Guo, dan Y. Yang, "Pretreatment of super viscous oil wastewater and its application in refinery," Pet. Sci., vol. 5, no. 3, hal. 269-274, 2008.

[90] S. Raghuvanshi, V. Bhakar, C. Sowmya, dan K. S. Sangwan, “Waste Water Treatment Plant Life Cycle Assessment: Treatment Process to Reuse of Water," Procedia CIRP, vol. 61, hal. 761-766, 2017. 